\title{
Cultural additivity in folktales: How Confucianism values are neglected in Vietnamese literature teaching?
}

\author{
Nguyen Thanh Thanh Huyen \\ Foreign Trade University, Hanoi, Vietnam \\ Ha Noi, January 1, 2020
}

The article "Cultural additivity: behavioural insights from the interaction of Confucianism, Buddhism and Taoism in folktales", written by Vuong et al. (2018) fills in the gap of syncretism, creolization and hybridity literature by discovering how the values and anti-values of the three influential religions (Buddhism, Confucianism and Taoism) incorporate in Vietnamese folktales. The article using Bayesian analysis does not only show the existence of cultural additivity phenomenon using but also provides some interesting interpretations of religious practices in Vietnam.

Vietnam is the land of ritual and religious practices. Vietnamese people have their own ancient traditions, worshipping Mother Goddess, historical heroes and ancestors. They also absorbed foreign religions (Buddhism, Confucianism and Taoism), unified and embraced them for the co-existence with the indigenous religious values. This integration can be recognized easily in sacred places. In shrines worshipping The religion of Four Palaces, statues of Mother Goddesses are placed under the Three Emperors (from Taoism) and Buddha respectively, representing the order of ruling power.

Despite the widespread of Buddhism, Confucianism and Taoism, few Vietnamese officially claim to practice any of them. That might explain why most Vietnamese do not strictly follow the religious ideas of neither Buddhism, Confucianism, nor Taoism. Instead, they are familiarized with these teachings through an intermediate - a rich collection of folktales, which have shaped their attitudes and behaviors since childhood. However, as the core values of these three religions are well blended in the folktales, few can tell the difference among their core values.

The work of Vuong et al. (2018) helps us understand how these cultures blend in folktales by encoding complicated religious ideas into binary data, then analyzing them with Bayesian analysis. Bayesian analysis is a powerful and unique methodology in the field that is conventionally ruled by the exploratory qualitative methodologies. The power of Bayesian analysis allows us to test complex relationships between these religious values. However, the origin of the encoded data is questionable, because they were drawn from 6 major sources, most of which were recorded by Confucian scholars. In addition to that, folktales usually surviving through word of mouth might have numerous versions, which might change how religious ideas were originally conveyed.

The research gives some important findings. While Buddhism remains isolated, there is evidence of the existence of cultural additivity between Confucianism and Taoism, especially 
when the story conveys key values of Confucianism. The authors attributed this to two reasons: 1) most stories were recorded by Confucian scholars; 2) Among three religions, only Confucianism and Buddhism established institutions in Vietnam. When Confucianism gained enough power to rule the court, they intentionally diminished Buddhism influence in the folktales, but still tolerated the existence of Taoism. A broader understanding about how contradicting ideas of these religions were added to the existing system is also provided. For example, Confucianism emphasises on the rigid hierarchy of the society, rules of conduct and moral obligations, some of which might be considered mundane and left behind in Taoism. The discussion on the contradiction between Buddhism and the other two religions further explained the isolation of Buddhism in folktales. Particularly, the path of Buddhism (e.g. non-attachment, to have compassion for everyone, the Eight-fold way) is far more demanding than that of Confucianism and Taoism.

Reading this article leaves me several thoughts:

(i) Confucianism values were embedded in many Vietnamese folktales taught at school, but why is the values of Confucianism mentioned in neither explanation nor discussion of the folktale?

Let's take an example from the compulsory literature curriculum for Vietnamese secondary student. "Truyện người con gái Nam Xương" (or “The story of a Nam Xuong woman”) promotes the 'Three Obediences of women' in Confucianism with several ideas in Taoism (Maxreading, 2019). Vu Thi Thiet - the main character - was condemned to be disloyal to her husband without having a chance to explain. Being forced to leave the house and willing to prove her dignity, Thiet decided to commit suicide. Since her grievances reached the god, she was exonerated but unable to return to the mundane world. At school, teachers rarely indicate the presence of Confucianism in the story: how it dictates unequal status between wife and husband and how a Confucian society leaves Thiet no choice but to die.

Although Confucianism idea led to Thiet's tragedy, it is not so obvious to students because the major causes of Thiet's tragedy are usually taught as "feudalism ideology", "husband jealousy", or "unequal marriage". Based on the work of Vuong, the lack of awareness about the presence of Confucianism in folktales might be attributable to: (i) teachers are incapable to see how Confucianism idea is embedded in this story (ii) the old-school educational system, which is heavily influenced by Confucian teaching "Ton su trong dao" (or "Be deferential to the teacher and respect their morals"), creates generations passive learning students not willing to question the teacher's saying; (iii) The dominance of Confucianism in Vietnamese life makes it challenging to be recognized.

(ii) This article points out the dominance of Confucianism in Vietnamese folktales. Different from Buddhism, which keeps its religious nature, Confucianism is harder to be distinguished as a religion or a rule of conduct. The later might attribute to why its teachings are so influencing and deep-seated in Vietnamese daily life, yet less present in sacred places. Acknowledging it as a rule of conduct, Vietnamese people might act accordingly to its core values, without much question. 
In general, the cultural additivity phenomenon can happen anywhere and in anything around us. Comprehensive studies of this phenomenon will aid our understanding of the origin of our culture and the process of cultural evolution. However, conducting such studies about cultural additivity is very challenging, especially in emerging countries, in which the scientific research structure is substandard. Therefore, acquiring proactive attitude (Vuong, 2019), maintaining public trust (Vuong, 2018), implementing appropriate data policies (Vuong, Ho, Nguyen, \& Nguyen, 2019; Vuong, La, et al., 2018; Wilkinson et al., 2016), and constructing open access scientific databases (Vuong \& Nguyen, 2016; Nguyen, Ho, Nguyen, \& Vuong, 2019; Vuong, 2016; Ho et al., 2019) are inevitably essential to promote the scientific development in emerging countries.

\section{References}

Ho, La, Nguyen, Vuong, Nghiem, Tran, ... Vuong. (2019). Health Care, Medical Insurance, and Economic Destitution: A Dataset of 1042 Stories. Data, 4(2), 57. https://doi.org/10.3390/data4020057

Maxreading. (2019). Chương 12: Chuyện người con gái Nam Xương [Chapter 12: The Story of a Nam Xuong Woman].

Nguyen, M.-H., Ho, M.-T., Nguyen, Q.-Y. T., \& Vuong, Q.-H. (2019). A Dataset of Students' Mental Health and Help-Seeking Behaviors in a Multicultural Environment. Data, 4(3), 124. https://doi.org/10.3390/data4030124

Vuong, Q. H. (2016). Data on Vietnamese patients' behavior in using information sources, perceived data sufficiency and (non)optimal choice of health care provider. Data in Brief, 7, 1687-1695. https://doi.org/10.1016/j.dib.2016.04.066

Vuong, Q.-H. (2018). The (ir)rational consideration of the cost of science in transition economies. Nature Human Behaviour, 2(1), 5-5. https://doi.org/10.1038/s41562-017-0281-4

Vuong, Q.-H. (2019). Breaking barriers in publishing demands a proactive attitude. Nature Human Behaviour, 3(10), 1034-1034. https://doi.org/10.1038/s41562-019-0667-6 
Vuong, Q.-H., Bui, Q.-K., La, V.-P., Vuong, T.-T., Nguyen, V.-H. T., Ho, M.-T., ... Ho, M.-T. (2018). Cultural additivity: Behavioural insights from the interaction of Confucianism, Buddhism and Taoism in folktales. Palgrave Communications, 4(1). https://doi.org/10.1057/s41599-018-0189-2

Vuong, Q.-H., Ho, M.-T., Nguyen, H.-K. T., \& Nguyen, M.-H. (2019). The trilemma of sustainable industrial growth: Evidence from a piloting OECD's Green city. Palgrave Communications, 5(1), 156. https://doi.org/10.1057/s41599-019-0369-8

Vuong, Q.-H., La, V.-P., Vuong, T.-T., Ho, M.-T., Nguyen, H.-K. T., Nguyen, V.-H., ... Ho, M.T. (2018). An open database of productivity in Vietnam's social sciences and humanities for public use. Scientific Data, 5, 180188. https://doi.org/10.1038/sdata.2018.188

Vuong, Q.-H., \& Nguyen, T.-K. (2016). Data on Vietnamese patients' financial burdens and risk of destitution. Data in Brief, 9, 543-548. https://doi.org/10.1016/j.dib.2016.09.040

Wilkinson, M. D., Dumontier, M., Aalbersberg, Ij. J., Appleton, G., Axton, M., Baak, A., ... Mons, B. (2016). The FAIR Guiding Principles for scientific data management and stewardship. Scientific Data, 3(1), 160018. https://doi.org/10.1038/sdata.2016.18 